\title{
The University Library As Learning Organization for Innovation: An Exploratory Study
}

\author{
Rena K. Fowler
}

\begin{abstract}
This study examines an innovating university library as a learning organization and explores the mechanisms by which organizational learning facilitates innovation. Both qualitative and quantitative methods are applied. Three levels of library activity-individual, departmental, and organizational-are studied. Three aspects of a learning organization model are considered: continuous learning, team learning, and shared vision. Internet use serves as the outcome variable, representing innovation. Through qualitative analysis, a series of vehicles for organizational learning is identified, and partial support for the model was established through quantitative analysis.
\end{abstract}

Human beings are not the only ones whose learning ability is directly related to their ability to convey information. As a species, birds have great potential to learn, but there are important differences among them. Titmice, for example, move in flocks and mix freely, whereas robins live in well-defined parts of the garden and for the most part communicate antagonistically across the borders of their territories. Virtually all the titmice in the U.K. quickly learned how to pierce the seals of milk bottles left at doorsteps. But robins as a group will never learn to do this (though individual birds may) because their capacity for institutional learning is low; one bird's knowledge does not spread. . . The best learning takes place in teams that accept that the whole is larger than the sum of the parts, that there is a good that transcends the individual. ${ }^{1}$

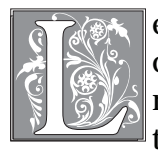

earning across territories becomes important when new innovations are introduced, as testified above by Arie P. De Geus, a Shell Oil executive quoting from a research article on ornithology. And university libraries today contend with a great deal of innovation in new technology, which is exacerbated by dynamic economic and market conditions. Central to technological change is adaptation to life on the information highway, the Internet, which some forecast to represent the "library" of the future. Confronted with this task, academic librarians struggle to understand the dimensions of the change and to find the means to accomplish it. In a 1993 article, "Organizational Change in Research Libraries," Susan Lee writes: "Today's research libraries 
face changes exceeding the scope of natural assimilation processes, and lack sufficiently comprehensive methods for adjusting and adapting to the turbulence. To enhance effectiveness, achieve excellence, and ensure survival research library leaders need, in full collaboration with staff members, to develop conscious, explicit processes for organizational change." 2

There is the sense within the field that investment now is demanded in both technological innovation and organizational change to accommodate it.

\section{Background}

A framework for understanding may be found in modern organizational theory and the concept of planned change, entailing "the use of valid knowledge and information as a basis for plans and programs of change." ${ }^{3}$ In the view of an early leader, Kurt Lewin, learning is critical to all processes, for people must learn to learn in order to change. ${ }^{4}$ Systems theory, prominent in this discipline, stresses the dependence of organizations on inputs from the environment. ${ }^{5}$ Alongside system theory, the management of corporate or organizational culture has been an important element in the study of planned change. Edgar H. Schein defines this as "the system of norms, beliefs and assumptions, and values that determine how people in the organization act-even when that action may be at odds with written policies and formal reporting relationships." 6

Within librarianship, surveys of this literature have been put forth by John $\mathrm{N}$. Olsgaard and Peggy Johnson. ${ }^{7}$ A number of dissertations in the field have investigated and found a positive relationship between participatory management and the introduction of some form of automation or technology, specifically those by Wilson Luquire, Larry N. Osborne, and Olsgaard. ${ }^{8}$ Charles R. Martell's The Client-Centered Academic Library, together with advocates for matrix management and experimentation, builds on this literature within academic librarianship. ${ }^{9}$

The study of organizational change logically relates to the more specific idea of introducing workplace innovation for which a separate, but related, body of literature exists. According to longtime researcher Everett M. Rogers, an innovation is an idea, practice, or object that is perceived as new by an individual or other unit. $^{10}$ Studies by those interested in the diffusion of innovations have dealt most successfully with the characteristics of an individual who innovates. ${ }^{11}$ Scholars have struggled in carrying theories to the organizational level where quantitative models have proven complex. ${ }^{12}$ Diffusion of innovation studies has been applied to libraries by several researchers, notably in a dissertation by Helen A. Howard and a research project of Jose-Marie Griffiths. ${ }^{13}$

Clarion calls for change have come forth from the business management literature of the 1980s and 1990s, adding to earlier research in the social sciences and management fields and reflecting national and international change in the workplace. ${ }^{14}$ The literature of librarianship has mirrored that of management in calling for change associated with technology in the field. ${ }^{15}$

With the growth of organizational studies, scholars and consultants have devised many techniques to aid the practicing manager to better understand and improve the workplace. From surveys and small-group discussions, these tools have been fashioned into multifaceted processes. Strategic planning has been especially popular, although in recent years it has been criticized as ineffective, overly bureaucratic, and irrelevant. Thus, strategic planning has been replaced by continuous planning, which treats planning as an evolving process, incorporating reference to the environment and plans adjusted based on learning. ${ }^{16}$ This contributes to the concept of the learning organization, defined by David A. Garvin, as one that is "skilled at creating, 
acquiring, and transferring knowledge, and at modifying its behavior to reflect new knowledge and insights." 17

The learning organization model has origins of its own in other threads of the literature for the management of change. ${ }^{18}$ Chris Argyris and Donald Schon say the process of organizational learning occurs "when members of the organization act as learning agents for the organization, responding to changes in the internal and external environments of the organization by detecting and correcting errors. ..."19 The learning organization now is regarded as a source of competitive advantage, and some think it the next logical step in the evolution of management thinking since World War II. ${ }^{20}$ Interest in the descriptive concept of organizational learning has given way to a focus on the more prescriptive learning organization, yet the models put forth do not yet offer a body of coherent theory or provide clear guidance for the practicing manager. ${ }^{21}$ Proposed sets of concepts seem overlapping and complex. Ideas by differing authors seem to represent alternative perspectives and terminology for like phenomena.

The best-known spokesperson for the concept in the 1990s has been Peter M. Senge, author of The Fifth Discipline. His book has effectively brought together many strands of thought that seem related and has become a best-seller in its field. Senge describes five components, or disciplines, that will lead to innovation in the learning organization, defined as "an organization that is continually expanding its capacity to create its future."22 These components are systems thinking, personal mastery, mental models, building shared vision, and team learning. Although much praised in the management field, the work also is regarded as "far too abstract." 23 Variant models have been offered by those in the field. ${ }^{24}$

A pair of researchers, Karen E. Watkins and Victoria J. Marsick, echo others but have tested their ideas through case stud- ies with many firms as reported in two books, Sculpting the Learning Organization and Creating the Learning Organization, and numerous articles. In Sculpting the Learning Organization, Watkins and Marsick say that the learning organization has six action imperatives: to create continuous learning opportunities; to promote inquiry and dialogue; to encourage collaboration and team-learning; to

Interest in the descriptive concept of organizational learning has given way to a focus on the more prescriptive learning organization,

establish systems to capture and share learning; to empower people toward a collective vision; and to connect the organization to its environment. They match these action areas against levels: individual, team, and organizational. Continuous learning is an individual activity, albeit often sponsored by the organization. Inquiry is associated with both individual and team activity. The establishment of systems and vision rests at the organizational level, and the connection to the external environment begins there..$^{25}$

The work of Senge and Watkins and Marsick constitute the fullest explications to date of the concept of the learning organization. Senge's is quite well known; Watkins and Marsick succeed in describing similar ideas in operational terms that may be more readily tested.

The literature of library management reveals parallel interests in planning and, in the past few years, the learning organization. Donald E. Riggs praised the latter concept in a 1997 editorial of College $\mathcal{E}$ Research Libraries. ${ }^{26}$ In a 1993 article, Shelley E. Phipps said: "Senge's idea of the learning organization is precisely what is needed in today's transformational academic research library. Learning about and utilizing his five disciplines provide a focus for developing the capa- 


\begin{tabular}{|c|c|c|}
\hline \multicolumn{3}{|c|}{$\begin{array}{c}\text { FIGURE 1 } \\
\text { Conceptual Framework for Study } \\
\text { Learning Organization As Model for Innovation }\end{array}$} \\
\hline Level & Learning & \\
\hline Organization & $\begin{array}{l}\text { Vision } \\
\text { System to share learning }\end{array}$ & \\
\hline Department & TEAM LEARNING & \\
\hline Individual & $\begin{array}{l}\text { Continuous Learning } \\
\text { Incorporates: } \\
\text { Systems to share learning } \\
\text { Vision }\end{array}$ & $\begin{array}{l}\text { Learning } \\
\text { Organization } \\
\text { As Process }\end{array}$ \\
\hline
\end{tabular}

with these management concepts and much knowledge has been gained; however, the means by which innovation is communicated or organizational learning occurs remain elusive. Thus, a study was undertaken to examine an innovating university library as a learning organization and to

bilities of libraries and librarians to develop the library organizations of the future." 27

Phipps of the University of Arizona and Maureen Sullivan of ARL now have offered a number of workshops to prepare participants for leadership roles in creating organizations that can learn and continuously improve quality and efficiency. They argue that libraries need to become learning organizations due to competition for services, new technologies, changing customer expectations, changing values in the workplace, and the challenges of higher education. ${ }^{28}$ Laura J. Bender, Phipps's colleague at the University of Arizona, has written of

\section{Use of the Internet was taken as a measure of innovation.}

Arizona's reorganization based on these principles. ${ }^{29}$ Yet another editorial, in $R e$ search Strategies, cautions that Senge's approach may be "just another shortlived, largely useless managerial ploy to motivate employees," although the editor notes the interest and relevance of the concept to librarianship. ${ }^{30}$ Such sentiments as these drive interest in the learning organization as academic libraries deal with change, especially technological change.

Thus, there has been considerable research in a number of fields associated understand the mechanisms by which organizational learning facilitates innovation. Use of the Internet was taken as a measure of innovation.

The learning organization model and organizational learning as a process may be viewed simultaneously from differing perspectives. The model may be examined in terms of the structure of the organization by level: individual, team, and organizational. At each of these structural levels, organizational learning may be woven into the fabric of organizational life. Within each level may be a set of strategies or technologies devised for and/or by staff who use technology to accomplish a task. Of these, the team is the major center of activity within the workplace. Through the team or group may be examined the presence of shared vision, team learning, and continuous or lifelong learning. Through the learning of individual staff are known the effects of organizational systems to capture and share learning. The learning organization model, seen through organizational processes, contributes to change and innovation. This framework is displayed in figure 1.

\section{Methodology}

A two-pronged study was designed to examine an innovating university library as a learning organization and to understand the mechanisms by which organizational learning facilitates innovation. 
Given its significance for library work, use of the Internet, encompassing the World Wide Web, was selected as the innovation to incorporate into the project. Three research questions were put forth:

1. How does organizational learning occur in a given university library today, and how does it contribute to the innovation process?

2. As part of this broad process, how does organizational learning contribute to use of the Internet and the Web as an innovation?

3. How does this learning and innovation match a learning organization framework based on the literature associated with management for change and innovation?

The first two questions were designed to explore the process by which organizational learning occurs and the third to incorporate a framework for testing a model, containing five more specific questions:

1. Within a university library work team, will individuals who engage in more continuous learning be more innovative?

2. Among members of a university library work team, will individuals who do more team learning be more innovative?

3. Among university library work teams, will teams that do more team learning be more innovative?

4. Among members of a university library work team, will individuals who share an organizational vision be more innovative?

5. Among university library work teams, will teams that hold a more strongly shared organizational vision be more innovative?

The methodology chosen to test these hypotheses was a case study drawing together both qualitative and quantitative forms of research to examine one organization and the departments within it as units of study. Qualitative data, drawn from interviews, were coded, classified, and measured against the model and process through explanation-building and a search for rival explanations. Quantitative data, collected to test the series of five hypotheses pertaining to the model for the learning organization, were tested by standard techniques for statistical analysis in the social sciences, including descriptive statistics, contingency tables, and regression. The principal independent variables were:

- continuous learning;

- team learning;

- shared vision.

Each was measured and scored through a series of questions to respondents. Data also were collected for a series of background variables. The dependent variable, use of the Internet, was measured through three factors:

- common uses of the Internet;

- tasks performed on the Internet;

- attitudes toward performance of work on the Internet.

Again, each was measured and scored through a series of questions to respondents.

As a case study of a single institution, many researchers would argue that its results cannot be generalized. That stand has been challenged by a proponent of case studies, Robert K. Yin, who maintains that such studies may be generalized to a theoretical framework and bolstered through multiple cases within a study. ${ }^{31}$ That effort was made in this study through analysis of multiple departments.

An ARL member served as the study site, chosen as one actively engaged in technological innovation, showing evidence of interest in qualities associated with the learning organization and characteristics that might be typical of a university library while affording leadership to others. Incorporated into the analyses were data for four of the library's divisions (Collections, Information Services, Automation \& Technical Services, and Access Services) and eleven departments 
(Special Collections and Archives, Special Archives, Bibliographers, Reference, Government Publications, Business Library, Engineering Library, Technical Services, Medical Library, Automation, and Access).

\section{Results}

1. How does organizational learning occur in a given university library today, and how does it contribute to the innovation process? Fourteen vehicles for organizational learning were identified from the remarks of those interviewed:

- formal training;

- informal training;

- formal communication;

- informal communication;

- team revelation or learning;

- organizational structure;

- the personnel system;

- planning;

- professional involvement;

- new technology;

- reading;

- exposure to a new perspective on one's position;

- leadership and initiative;

- internal and external stimuli.

These were accompanied by a series of incentives and barriers to organizational learning generally and, more particularly, the elements studied in the project (continuous learning, team learning, and shared vision). As part of the broader question, those interviewed were asked how library users drive organizational learning, a question with which many struggled before identifying series of:

- positions to take;

- formal or informal tools to use;

- hindrances to overcome;

- counterpositions.

Organizational learning was found to drive innovation by:

- priming the organization for innovation;

- empowering staff;

- joining other drivers.
Some said it lacked a uniform effect or suggested that innovation drives learning.

2. As part of this broad process, how does organizational learning contribute to use of the Internet and the Web as an innovation? Respondents reported positively that it:

- aided the institutionalization of the Internet within the workplace;

- encouraged creativity in thinking;

- helped librarians find a new role;

- offered vehicles to learn about the Internet;

- produced an environment for innovation.

Some could not explain how it helped or interpreted the Internet itself as a vehicle for organizational learning. Some incentives and barriers to Internet use reflected the unique aspects of the Internet, especially its disorganization, lack of quality control, and speed of change. In projecting future uses and characterizing the library of the future, those interviewed demonstrated just how the Internet primes people for change and empowers staff to look ahead and recognize new possibilities.

When asked how they learned about the Internet, respondents offered a fairly straightforward list of activities. These activities fitted generally within the broader framework for organizational learning, although, again, some were unique to the Internet's own nature. When asked how their attitudes toward the Internet had developed or changed over time, responses formed a sort of historical summary of its development. Participants described their experiences with online searching, electronic mail, listservs, and the Web. Their memories attest to how it gave them the means to learn new skills in the past and prepared them for new developments.

Asked why they used the Internet, the respondents' answers fell into a number of purposes, namely:

- as a tool, for communication;

- for work tasks; 
- to provide information services;

- to provide resources;

- for purposes apart from work ;

- for an advantage.

Beyond these specifics, they were asked how they thought the Internet might be used in the future for library work. The areas of application put forth were:

- support a librarywide information system;

- deliver improved information service;

- deliver more information electronically and remotely;

- aid distance education;

- offer librarians a new role in teaching;

- permit interactive user education;

- promote electronic publishing;

- aid greater collaboration via the Internet;

- improve work processes electronically;

- improve library research;

- change staffing needs;

- change use of physical space;

- aid services for the disabled.

These questions also revealed how librarians forecast the redesign of their work and aim for a user-centered environment for the services. Despite uncertainties, those interviewed believed the Internet and the Web were here to stay.

3. How does this learning and innovation match a learning organization framework based on the literature associated with management for change and innovation? Profiles by individual department and division portrayed the outstanding responses of those interviewed from each unit, in keeping with the goal of comparing teams or departments. When the ability to generate factors associated with organizational learning and its incentives and barriers were compared across all units, two departments (Medical Library and Reference) and one division (Information Services) stood out.
Quantitative methods were adopted to test five specific hypotheses tied to the third question. In each case, partial support was found for the hypothesis, based on statistical tests using regression or ANOVA with measures of continuous learning, team learning, and shared vision entered by department and division as independent variables. Three measures of Internet use served as the dependent or outcome variables. The questions and significant outcomes were:

- Within a university library work team, will individuals who engage in more continuous learning be more innovative? Responses from the Information Services Division and two departments, Government Publications and Technical Services, were significantly associated.

- Among members of a university library work team, will individuals who do more team learning be more innovative? Responses from the Information Services Division and two departments, Bibliographers and Automation, were significantly associated on at least one of the three outcome measures.

- Among university library work teams, will teams that do more team learning be more innovative? Responses from the Information Services Division and three of seven departments-Medical Library, Government Publications, and Reference-were significantly associated and contributed to a greater score for innovation.

- Among members of a university library work team, will individuals who share an organizational vision be more innovative? Only responses from the Information Services Division were significantly associated.

- Among university library work teams, will teams that hold a more strongly shared organizational vision be more innovative? Responses from the Information Services Division and three of seven departments-Medical Library, Government Publications, and Reference-were significantly associated and contributed to a greater score for innovation. 
- When qualitative and quantitative results were examined together by department and division, surprisingly similar results were found. One division and three departments offered the most consistently significant statistical results and stood out in the qualitative interviews. These were the Information Services Division and these departments-Government Publications, Medical Library, and Reference. Three other departmentsBibliographers, Technical Services, and Automation-were evident in some statistical analyses.

\section{Skewed results and the lack of variance can affect the ability to find significance, and those may well be factors in the failure to find some results to report.}

When background factors and the principal independent variables were examined with the outcome variables by division, two factors were significant with the outcome variables:

- hours of professional reading;

- numbers of papers published.

Of the three independent variables, the one most often significant with the three outcome variables when tested in combination with other variables was continuous learning.

Those interviewed were asked how their own library might be or become a learning organization. Most, answering briefly, thought they were in the process of becoming a learning organization.

Lastly, survey responses to this question did not result in normal distributions. Skewed results and the lack of variance can affect the ability to find significance, and those may well be factors in the failure to find some results to report. There are several other cautionary notes regarding the findings: Inferential statistical techniques have been applied to a population, not a sample; and this case study is based on a measurement at one point in time.

\section{Conclusions}

Upon examining the analysis broadly, there is support for this model, as displayed in figure 1, and elements of it may be useful to both practitioners and theorists. However, the support is partial, the model is incomplete, and questions arise from the data that might be pursued by others. Overall, the relationships may be more complex and more dynamic than portrayed in the model.

The results of this study offer evidence that organizational learning occurs through a series of vehicles that function at one or more of the levels identified: individual, departmental or team, and organizational. The list of fourteen vehicles identified might provide the basis to better specify types of tools to advance organizational learning in differing arenas. At each level, there exist barriers and incentives to organizational learning, as reported by those interviewed. Some of these appeared in the list of background variables tested statistically. Of these, only two showed a significant relationship with innovation in this study: professional reading and number of publications authored. These pieces of information may be useful in encouraging continuous learning among librarians, but further research is needed. One respondent maintained that professional connections for librarians ought to extend beyond the field as it has been defined, an aspect not covered by this study but perhaps meriting attention in a field that is rapidly changing.

The model and process shaping this project, outlined in figure 1 , do not adequately describe the relationship between organizational learning and innovation, as it emerged in this study. Based on the preponderance of the qualitative data, organizational learning might drive innovation because it primes individuals and teams for innovation, and it can empower people in the workplace.

Use of the Internet, including the Web, was the particular innovation that served 
as an outcome variable in this study. Individual initiative is a necessity, but organizational learning may promote use of the Internet by creating new uses for it, suggesting new roles for librarians through their work with the Internet and institutionalizing the Internet in the workplace. Thus, organizational learning, at every level, may move the group toward innovation. However, by seeking out and studying potential rival explanations offered in the interviews, another aspect of the relationship between organizational learning and innovation appeared-its iterative nature. Learning and innovation in an academic library may fuel each other. Learning may lead to innovation, leading to more learning about and with that innovation and more innovation. That may apply to use of the Internet, but there is insufficient evidence to say more because testing that point was not an aim of this study. A better diagram would incorporate a relationship with innovation, even in an incomplete form.

This model and process did not broadly encompass the stimuli to organizational learning and innovation, either internally or externally. Yet, these forces were raised in the interviews and one question in the study did elicit data on the ways that users might drive organizational learning. This was a question that respondents found very difficult to answer. A number of them named informal as well as organizational tools. Others described the condition or relationship between them and their users, or named hindrances to knowing user need, or said that user needs either did not or should not drive organizational learning. Overall, user needs did not seem well understood, perhaps an area for future research, as suggested by one of those interviewed.

The uncertainty surrounding the users' role also might affect shared vision. Technology and economic conditions are thought to be the major drivers of innovation. Technology is the apparent force behind the need for staff with new skills and ideas. Although those interviewed were convinced of the imperative to change, some spoke of a desire for a more evolutionary process, offering that some users would prefer this. The comments in the interviews might suggest that the commitment to change at this university, and perhaps at others, may be driven by factors in the broader environment for

\section{Learning and innovation in an academic library may fuel each other.}

higher education and information technology industry, especially the expectation or anticipation of change. Some of those interviewed expressed the concern or fear that, without adaptation to technological change, the library risks becoming irrelevant. This may lead to action based on a search for competitiveness. Under dynamic and uncertain circumstances, there may be confusion in understanding just what factors are driving change. The relationships among the factors may be difficult to assess, topics that extend beyond the scope of this study.

The model contained levels of learning within the organization: individual, departmental (meaning team), and organizational. Team learning was particularly highlighted in the model as central to the process of organizational learning. One of those interviewed raised the possibility that the three levels might represent a progression, that individual learning is required before team learning and team learning before shared vision. Despite some intuitive logic in that idea, it has not been demonstrated through the data. From the quantitative analysis, there is evidence that continuous learning is a critical foundation for innovation when these three levels of learning are compared together with innovative activities. Perhaps team learning and continuous learning are more equal partners than has 
been outlined in this researcher's model. The relationship between continuous learning and team learning ought to be better understood if both are to be pursued effectively in the workplace.

Relationships between shared vision and innovation were the hardest to establish. Within departments, this was not established, although it was found within one division. In comparing departments, significant differences were found. The three departments in which shared vision contributed to a mean score for innovation were the same ones that demonstrated significant relationships between team learning and innovation. These outcomes, in combination with the interviews, support the idea that team learning does precede and contribute to shared vision. When shared vision was examined only with background variables, significant relationships were found with age, professional reading, and committee service. These relationships might bear further study. At this point, no evidence was found to show how continuous learning might incorporate systems to share vision, as presented in the diagram.

The statistical analysis testing the five hypotheses tied to the third research question gave partial support to each hypothesis. One division of the three analyzed and three departments of the seven analyzed demonstrated statistically significant relationships that supported the tie between one or more of these levels of organizational learning and innovation.

This study was introduced with a quotation by Arie P. De Geus. He described the superior ability of titmice, birds who fly rather freely in flocks, to learn collectively when compared to robins, who prefer to remain in more defined territories. In its broadest sense, this project will have succeeded if the reader has found clues to understanding the success of the titmice.

\section{Notes} 74.

1. Arie P. De Geus, "Planning as Learning," Harvard Business Review 66 (Mar./Apr. 1988):

2. Susan Lee, "Organizational Change in Research Libraries," Journal of Library Administration 18 (1993): 129.

3. Kenneth D. Benne, Warren G. Bennis, and Robert Chin, "Planned Change in America," in The Planning of Change, 4th ed., eds. Warren G. Bennis, Kenneth D. Benne, and Robert Chin (New York: Holt, Rinehart, and Winston, 1985), 19.

4. Robert Chin and Kenneth D. Benne, "General Strategies for Effecting Changes in Human Systems," in The Planning of Change, 4th ed., eds. Warren G. Bennis, Kenneth D. Benne, and Robert Chin (New York: Holt, Rinehart, and Winston, 1985), 31.

5. Daniel Katz and Robert L. Kahn, The Social Psychology of Organizations, 2nd ed. (New York: John Wiley and Sons, 1978), 30-33. 6.

6. Edgar H. Schein, Organizational Culture and Leadership (San Francisco: Jossey-Bass, 1985),

7. John N. Olsgaard, "Automation As a Socio-Organizational Agent of Change: An Evaluative Literature Review," Information and Technology and Libraries 4 (Mar. 1985): 19-28; Peggy Johnson, Automation and Organizational Change in Libraries (Boston: G. K. Hall, 1991), 21-56, 83101.

8. Wilson Luquire, "Attitudes toward Automation/Innovation in Academic Libraries," Journal of Academic Librarianship 8 (Jan. 1983): 344-46; Larry N. Osborne, "Predictors of Satisfaction with Automated Library Circulation Systems" (Ph.D. diss., Univ. of Pittsburgh, 1983), 138; John N. Olsgaard, "The Relationship between Administrative Style and the Use of Computer-Based Systems: An Attitudinal Study of Academic Library Professionals" (Ph.D. diss., Univ. of Illinois at Urbana-Champaign, 1984), 170.

9. Charles R. Martell Jr., The Client-Centered Academic Library: An Organizational Model (Westport, Conn.: Greenwood Pr., 1983), 67; Hugh F. Cline and Loraine T. Sinnott, The Electronic Library: The Impact of Automation on Academic Libraries (Lexington, Mass.: Lexington Books, 1983), 173-74; Peggy Johnson, "Matrix Management: An Organizational Alternative for Libraries," 
Journal of Academic Librarianship 16 (Sept. 1990): 225; Joanne R. Euster, "The New Hierarchy: Where's the Boss?" Library Journal 115 (May 1, 1990): 44; Ann De Klerk and Joanne R. Euster, “Technology and Organizational Metamorphoses," Library Trends 37 (spring 1989): 462-68.

10. Everett M. Rogers, Diffusion of Innovations, 4th ed. (New York: Free Pr., 1995), 11.

11. Ibid., 252-66.

12. Ibid., 378-79; Gerald Zaltman, Robert Duncan, and Jonny Holbek, Innovations and Organizations (New York: John Wiley and Sons, 1973), 178-83; George P. Huber and William H. Glick, eds., Organizational Change and Redesign: Ideas and Insights for Improving Performance (New York: Oxford Univ. Pr., 1993), 215-47.

13. Helen A. Howard, "Creating Your Library's Future through Effective Strategic Planning," College \& Research Libraries 42 (Sept. 1981): 425-33; Jose-Marie Griffiths et al, Diffusion of Innovations in Library and Information Science, Final Report, ERIC, ED 279350 (Rockville, Md.: King Research; Andover, Mass.: Network, 1986), 190-208.

14. Rosabeth Moss Kanter, The Change Masters: Innovations for Productivity in the American Corporation (New York: Simon and Schuster, 1983), 27-28, 50; Peter Drucker, The Age of Discontinuity: Guidelines to Our Changing Society (New York: Harper and Row, 1969), 10; Tom Peters, Thriving on Chaos: Handbook for a Management Revolution (New York: Alfred A. Knopf, 1988), 34, 27; Michael Hammer and James Champy, Reengineering the Corporation: A Manifesto for Business Revolution (New York: Harper Business, 1993), 1-35; John Naisbitt and Patricia Aburdene, Re-inventing the Corporation: Transforming Your Job and Your Company for the New Information Society (New York: Warner Books, 1985), 145-78.

15. Donald E. Riggs, Creativity, Innovation, and Entrepreneurship in Libraries (New York: Haworth Pr., 1989), 1; Lauren H. Seiler and Thomas T. Surprenant, "The Virtual Information Center: Scholars and Information in the Twenty-First Century," in Libraries and the Future: Essays on the Library in the Twenty-First Century, ed. F. W. Lancaster (New York: Haworth Pr., 1993), 157, 178-79; F. W. Lancaster, "Whither Libraries? or, Wither Libraries," College \& Research Libraries 50 (July 1989): 407; Johnson, Automation and Organizational Change in Libraries, 132-33; Lee, "Organizational Change in Research Libraries," 129-30; Richard M. Dougherty and Carol Hughes, Preferred Futures for Libraries: A Summary of Six Workshops with University Provosts and Library Directors (Mountain View, Calif.: Research Libraries Group, 1992), 1-19; idem, Preferred Library Futures II: Charting the Paths (Mountain View, Calif.: Research Libraries Group, 1993), 1-25; Miriam A. Drake, "Technological Innovation and Organizational Change," Journal of Library Administration 19 (1993): 40, 51.

16. Charles Handy, The Age of Paradox (Boston: Harvard Business School Pr., 1994), 11; John C. Redding and Ralph F. Catalanello, Strategic Readiness: The Making of the Learning Organization (San Francisco: Jossey-Bass, 1994), 21-24.

17. David A. Garvin, "Building a Learning Organization," Harvard Business Review 71 (JulyAug. 1993): 80.

18. Dave Ulrich, Mary Ann Von Glinow, and Todd Jick, "High Impact Learning: Building and Diffusing Learning Capability," Organizational Dynamics 22 (fall 1993): 53; Kenneth D. Benne, "The Processes of Re-education: An Assessment of Kurt Lewin's Views," in The Planning of Change, 4th ed. (New York: Holt, Rinehart, and Winston, 1985), 273-76.

19. Chris Argyris and Donald Schon, Organizational Learning: A Theory of Action Perspective (Reading, Mass.: Addison-Wesley, 1978), 29.

20. Ray Stata, "Organizational Learning-The Key to Management Innovation," Sloan Management Review 31 (spring 1989): 64.

21. Eric W. K. Tsang, "Organizational Learning and the Learning Organization: A Dichotomy between Descriptive and Prescriptive Research," Human Relations 50 (Jan. 1997), 84-85.

22. Peter M. Senge, The Fifth Discipline: The Art and Practice of the Learning Organization (New York: Doubleday Currency, 1990), 5-10, 14.

23. Garvin, "Building a Learning Organization," 79.

24. Ulrich, Von Glinow, and Jick, "High Impact Learning," 62-64; Joop Swieringa and Andre Wierdsma, Becoming a Learning Organization: Beyond the Learning Curve (Wokingham, England: Addison-Wesley, 1992), 55-58, 74.; Daniel R. Tobin, Re-educating the Corporation: Foundations for the Learning Organization (Essex Junction, Vt.: Oliver Wight Publications, 1993), 14-23; Edwin C. Nevis, Anthony J. DiBella, and Janet M. Gould, "Understanding Organizations As Learning Systems," Sloan Management Review 36 (winter 1995): 73-77; Redding and Catalanello, Strategic Readiness, xiii, 5-12; Michael J. Marquardt, Building the Learning Organization: A Systems Approach to Quantum Improvement and Global Success (New York: McGraw, 1996), 19-28.

25. Karen E. Watkins and Victoria J. Marsick, Sculpting the Learning Organization: Lessons in the Art and Science of Systemic Change (San Francisco: Jossey-Bass, 1993), 14-18, 99-102; idem, 
Creating the Learning Organization (Alexandria, Va.: American Society for Training and Development, 1996), 4-6.

26. Donald E. Riggs, "A Commitment to Making the Library a Learning Organization," College EResearch Libraries 58 (July 1997): 298.

27. Shelley E. Phipps, "Transforming Libraries into Learning Organizations-The Challenge for Leadership," Journal of Library Administration 18 (1993): 21.

28. —_ "Transforming Culture: The Role of Leadership in Creating the Learning Organization," faxed notes from speech, 1994.

29. Laura J. Bender, "Team Organization-Learning Organization: The University of Arizona Four Years into It," Information Outlook 1 (Sept. 1997): 19-22.

30. Barbara Wittkopf, "Is Your Library a Learning Organization," Research Strategies 13 (winter 1995): 3.

31. Robert K. Yin, Case Study Research: Design and Methods, 2nd ed., Applied Social Research Methods Series, Vol. 5 (Thousand Oaks, Calif.: Sage, 1994), 10, 31-32. 